\title{
CHAPTER 6. EXPLICIT SOCIAL COSTS OF CRIME IN A TIME OF CRISIS - COSTS OF LAW ENFORCEMENT IN THE DRIVERS' CRIMES
}

\author{
Tânia DIAS ${ }^{1}$ \\ Pedro SOUSA ${ }^{2}$
}

\begin{abstract}
:
By defining some behaviors as crimes, law defines incentives and protects society from direct and indirect, tangible and intangible negative impacts. Whatever the severity of the prescribed penalties for those that prevaricate, society and its institutions need to act at the level of law enforcement; otherwise, rules may not be viewed as credible. Therefore, besides all expenses incurred by actual and potential victims and those incurred by offenders, when computing the costs of crime, one must also take into account the enforcement costs. Focusing on two types of drivers' crimes - driving under the influence of alcohol and driving without legal license controlled in Oporto city, in this chapter we aim to present estimates about its enforcement law costs for the period 2007-2010, and, at the same time, to design a methodological guide to accomplish this target in similar legal contexts. In the end, we conclude that the enforcement law costs in Oporto and in that period almost reached the barrier of an average of 1,000,000 Euros per year, value that meant the sacrifice correspondent to the contribution of 61 productive Oporto citizens for the Portuguese Gross Domestic Product. The knowledge of this information by society and by their elected representatives is especially important when making public costbenefits analysis in times of economic crisis.
\end{abstract}

Key words: Costs of crime, Law enforcement, Cost-benefit analysis

JEL Classification: D61, H59, K14, K42

\section{INTRODUCTION}

Most of our decisions depend on a comparison between marginal costs and benefits, mainly the visible or the direct ones. In that computation, usually, we forget that we

\footnotetext{
${ }^{1}$ Tânia Dias, Master in Criminology, Faculty of Law, University of Porto.

2 Pedro Sousa, PhD in Economics, Assistant Professor, Faculty of Law and School of Criminology, University of Porto. Address: Rua dos Bragas, 223. 4050-123 Porto. Portugal.
} 
live in an interconnected world where our actions can produce negative or positive externalities that will impact on others. In order to correct the effects of this inattentiveness, society use several mechanisms, like public policy instruments, such as taxes and subventions, and also rules fixed in the law.

Law defines incentives and restricts ones for acting badly, i.e., acting against others' property rights, by penalizing and criminalizing selected behaviours considered as negative by elected society representatives. Therefore, legally typified crimes appear in order to protect society from direct and indirect, tangible and intangible, negative impacts. The main reason for this is a widespread social reliance on the idea that crimes create costs, and a belief in the existence of an optimal level of deterrence that it is favoured by a certain degree of law enforcement (see, e.g., Garoupa, 1997, and Polinsky \& Shavell, 2000, inter alios). In order to be credible and effective in conditioning behaviours, law must be enforced, especially in those cases typified as crimes, although at the expenses of the society. Hence, one can easily realize that in order to reduce or eliminate social and individual losses caused by criminal behaviours, society is called to finance the enforcement of law. In another words, costs are incurred to prevent other types of costs.

The impact of crime on society, henceforth, must be understood by considering the two sides of the coin - the side of the actual and potential crime effects on the main actors (victims and offenders), and the side of law enforcement (and corresponding entities and organisations). In times of economic and financial crisis, where it is of utmost importance to be more careful when expending public resources, studies about the costs of crime and, specifically, how much law enforcement mechanisms cost, are justified because they permit more informed debates on cost-benefit and cost-effectiveness analysis, allowing to conclude about the efficiency of a program in reducing crime, and to achieve better decisions in crime reduction that could lead to substantial savings for individuals, for private corporations and for the public sector (Brand \& Price, 2000; Farrell, Bowers \& Johnson, 2004).

Costs of crime have being studied by several researchers, in some western countries such as France (Godefroy and Laffargue, 1980 and 1989; Palle and Godefroy, 1998), United Kingdom (Brand \& Price, 2000), USA (Cohen, 1988; Cohen, 1990; Miller, Cohen \& Rossman, 1993; Miller, Cohen \& Wiersema, 1996; Anderson, 1999), and Australia (Mayhew, 2003; Rollings, 2008). Differently, in Portugal, scientific studies like those are rare, being Soeiro and Teixeira (2010) an exception in recent years.

With this chapter, we aim to contribute to this literature, by revealing empirical evidence. We focus on the costs supported by the Court and the Prosecution Office due to two types of drivers' crimes (driving under the influence of alcohol, drugs and psychotropic substances, and driving without legal license), that did took place at 
Oporto city, between 2007 and 2010. Contrarily to all expectations, in Portugal, characterized by deep public finance problems to solve and by recurrent discussions about the efficiency of the justice system, organised and systematic empirical evidence as revealed in this chapter has not been available; as we know, this study is the first one ever done.

Because in this study it has been required to take several decisions about how to collect, select and organize data, this chapter is useful, also, as a methodological guide to compute these types of costs of crimes in similar contexts.

This chapter is organized in five sections. After this introduction, in section 2 we define the concept of costs of crime and present a brief review of the literature. After section 3 where we explain the objectives of this chapter, section 4 is dedicated to present empirical evidence. Before references, section 5 concludes the chapter.

\section{CONCEPT OF COSTS OF CRIME AND LITERATURE REVIEW}

The concept of cost is crucial in Economics, science that is devoted to the study of the allocation of scarce resources to alternative uses. Cost can be defined as the "(...) value of resources sacrificed in order to obtain a desired good or service or, alternatively, to avoid some unpleasant good or service" (Czabanski, 2010, p. 9), and it is fundamental in cost-benefit and cost-effectiveness analysis. Costs of crime are those related to crime.

According to Davidson (1999, cit. in. Brand \& Price, 2000), there are three categories of costs of crime: costs in anticipation of crime; costs as a consequence of crime; and costs in response to crime. The first category covers all costs incurred prior to the criminal event in an attempt to reduce their likelihood or the negative consequences that may arise from it (e.g., passive protection mechanisms for home and insurance contracts). The second includes the costs directly related to the crime (e.g., medical treatment in case of personal offenses, and value of stolen goods). Finally, the third accounts for all costs incurred in responding to crime (e.g., police and court expenses). It is possible to divide those costs according to another classification tangible and intangible, costs. The first ones are those that "(...) involve monetary payments such as medical costs, stolen or damage property, wage losses (...)" (Cohen, 2000, p. 281). These costs are easier to measure because its monetary value is quoted on the market (Albertson \& Fox, 2008). Intangible costs, in turn, are those whose objects are not susceptible of public or private market transaction, as it is the 
case of fear, suffering and loss of quality of life (Cohen, 2000; Roper \& Thompson, 2006; and Detotto \& Vannini, 2010, inter alia) ${ }^{3}$.

As mentioned in the introduction, in the literature we find a very large number of studies on the costs of crime. However, among these numerous studies, there are few contributions focused on the costs of the drivers' crimes, and no one calculates the costs of law enforcement in these crimes. Instead, there are studies that estimate the costs of road accidents that have criminal origin, i.e., they focus mainly on costs as a result of road crime. For example, in France, Godefroy and Laffargue (1995) proceeded to the calculation of the costs of involuntary attacks to human life, which included people who lost their lives and those who were injured as a result of road accidents where the author was criminally responsible. Using the value of human life and the number of victims, the authors concluded that the costs of involuntary attacks to human life in the context of traffic accidents for the years 1988, 1989, 1990 and 1991 were, in millions of francs: 29051, 31125, 31260 and 30144, respectively. In another study, Palle and Godefroy (1998) estimated the cost of road accidents with criminal origin imposed to the same country between 1991 and 1996. For the USA, Miller et al. (1996) computed the costs for victims of road accidents whose author was under the influence of alcohol, for the year 1993. For the UK, Brand and Price (2000), considering data from the Department of Environment, Transport and the Regions estimated the costs of traffic accidents involving the behaviour of driving with excessive speed, in 1998. In their study, they included the loss of productivity, medical care and human costs, concluding that the accidents from which resulted human life losses had a total cost of 314 million pounds. In addition to the costs as an outcome of crime, Brand and Price (2000) also calculated reaction costs to crimes committed in road context, though without specifying what acts were included. They concluded that the costs to the police were 1,260 million pounds and costs to the justice system were around 1,340 million pounds.

Another large group of studies included the costs of road accidents, regardless of criminal origin, and there are several attempts at this level of estimation.

Christe and Soguel (1996) conducted a study in three Swiss cantons, in which they asked for the willingness to pay (WTP) to avoid the consequences arising from a traffic accident (e.g., human life losses, loss of life expectancy, physical and mental suffering), using two contexts: in the first, respondent took the role of victim, and in

\footnotetext{
${ }^{3}$ There is a wide discussion related to the most appropriate methodology for the measurement of intangible costs. See discussion in Cohen (1988); Cohen and Miller (2003); Cohen et al. (2004); Atkinson, Mourato and Healey (2005), Dolan et al. (2005); Dolan and Moore (2007); and Dolan and Peasgood (2007).
} 
a second scenario the respondent assumed the role of a hypothetical family of the victim. The objectives of the study were, on the one hand, to value human and social costs of traffic accidents and, on the other, to estimate separately the costs of accidents for the victims and their families. They concluded that the WTP to avoid his own death ascended to a value of 1,700 thousand Swiss francs, while the WTP for the avoidance of an accident that involves severe and permanent damage was 1,750 thousand of francs. The WTP, in the case of the respondent be a relative of the victim, to avoid death was about 2 million francs, while the WTP to prevent permanent and severe damage was about 2,100 thousands of francs.

In Portugal, studies are located in the latter group of works. In fact, authors computed the costs that road traffic accidents generate in this country, regardless of the source be criminal or not. Graça and Ramos (2000) concluded that, from January till October 2000, there was a daily average of almost five deaths (4.6) and 19 serious injuries. Based on data from the Portuguese Road Prevention institution, according to which each of the fatalities implied an average socio-economic cost of 200 thousand Portuguese Escudos (998,000 Euros), they stress that this scenario involved a daily expenditure of at least about 1 million Portuguese Escudos (4,988 thousand Euros). Specifically, in what respects to the enforcement costs in the cases of drivers' crimes, we haven't found any reference in the literature.

\section{OBJECTIVES}

In this chapter, we aim to estimate the costs of law enforcement in the case of drivers' crimes - driving under the influence of alcohol, drugs or psychotropic substances ${ }^{4}$ (Penal Code, article 292) and driving without legal license (Decree-Law No. $2 / 98$, article 3). Specifically, the objective was to calculate the costs generated to society, evaluated by the costs supported by the Judicial System institution that has been directly involved, namely, the court "Tribunal de Pequena Instância Criminal do Porto" and the Prosecution Office located in this court. The selection of these organizations was guided by the purpose to analyse those institutions involved in the prosecution and punishment of drivers' crimes.

This study has been restricted to the city of Oporto (Portugal), because of the proximity to the School of Criminology and due to the aim of considering a large city, and to the period 2007-2010, due to the need to consider reliable data, which exists only after 2007 with accurately updated records. We used statistical data about the

\footnotetext{
${ }^{4}$ Although this is the legal designation of the crime, in this chapter will only be considered the behavior of driving under the influence of alcohol due to lack of statistical relevance of driving under the influence of drugs or psychotropic substances.
} 
incidence of the criminal processes and about the budget implementation of the Criminal Court "Tribunal de Pequena Instância Criminal of Porto" and of the Prosecution Office.

\section{EMPIRICAL EVIDENCE}

\section{Methodological procedures}

In order to compute the costs of the Prosecution Office and of the Criminal Court, initially it has been essential to sum all expenses incurred by these institutions during the time period under analysis. The costs were divided into three main groups: "staff-related costs", "operating expenses" and "building use cost".

According to the Decree-Law No. 26/2002 that defines staff-related costs, these must be divided into three categories - "certain and permanent salaries", "eventual and variable allowances", and "social security".

Regarding "staff-related costs", it was found that locally there was no record of the amount spent with the people that worked in the prosecution and judgment of these crimes, as the salaries are directly processed by the Public Department named Direção-Geral da Administração da Justiça. For this reason, we chose an alternative strategy to compute these costs: firstly, we collected data about the number and professional status of employees who held office in these institutions, during the period. Then, through the consultation of the payment system of Public Administration was possible to calculate the annual costs of Court and Prosecution Office's staff. To this value it was added the holiday and Christmas extra payments ${ }^{5}$, and the amount of money paid by the employer (in this case, the State), to Social Security.

In what respects to the "operating expenses", data has been obtained from the Court's financial records about expenses with consumed goods and services.

Finally, we added the costs of the building use. The building occupied by the Criminal Court and by the Prosecution Office belongs to the State (Government), consequently, there is not a direct and explicit expense for its use. For that reason, we evaluated the use of the building considering its opportunity cost, which has been estimated taking into account the value of the highest valuable alternative use

\footnotetext{
5 Accruing to the twelve salaries, each year employers used to receive two additional remunerations called "holiday and Christmas extra payments".
} 
that it can have (renting market). For this task, we used the market annual average value per square meter for the same area of the Court and of the Prosecution Office. After obtaining the total sum of expenses, its allocation to the crimes in reference respected their shares in the total crimes that were processed by both institutions.

Finally, we compared the yearly values with each other and with the per capita Gross Domestic Product in order to get a clear picture of the studied theme.

\section{Partial empirical results}

The component "staff-related costs" is comprised of salaries of the employees, holiday and Christmas extra payments, meal allowance, and contribution rate paid by the employer to the social security system, observing the following formula:

$$
A A=12 \times[M B R \times(1+C R)+(D F A \times W D)]+2 \times[M B R \times(1+C R)]
$$

Where:

AA: Annual amount spent by the Government with an employee of the Prosecution Office and Criminal Court;

MBR: Monthly basic remuneration;

CR: Contribution rate paid by the employer;

DFA: Daily food allowance;

WD: Working days per month.

Clarifying, the annual amount spent by the Government with an employee of the Prosecution Office / Criminal Court (AA) is equal to twelve ordinary monthly payments plus two extra payments (holiday and Christmas extra payments). Both ordinary and extra payments include a contribution to the Social Security System (paid by the employer) (CR) and the monthly basic remuneration (MBR) ${ }^{6}$. Besides those payments, the annual amount includes also, for each working day, the daily food allowance (DFA), whose value has been found by consulting legislation.

In the end of these calculus procedures, we obtained the following conclusions about the "staff-related costs" of the Prosecution Office and of the Criminal Court: in 2007, it was spent 1,076,629.56 Euros; in 2008, this figure amounted to 1,060,075.41 Euros; in 2009, 1,188,469.10 Euros and, in 2010, the expenditure was 1,138,684.28 Euros (Figure 1).

\footnotetext{
${ }^{6}$ Vide Direção-Geral da Administração e do Emprego Público (2007, 2008, 2009, 2010). As each employee position had different levels, and as there was no information on which level were the employees of Prosecution Office and Criminal Court, we chose to compute the average value of the basic pay levels.
} 
Figure 1: "Staff-related costs" that served in Prosecution Office and Criminal Court (2007-2010)

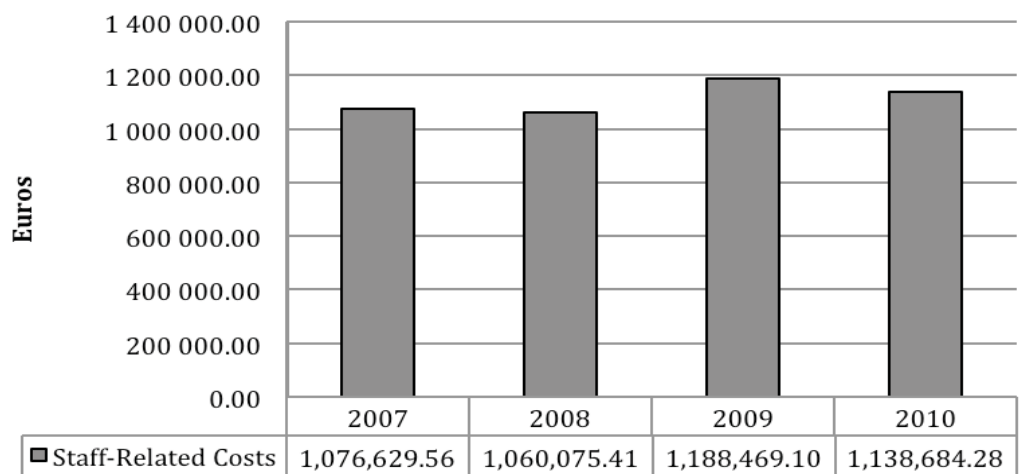

Source: Elaborated by the authors from data provided by the Criminal Court; Contributory System of Public Administration; various laws. Current prices, in Euros.

Data for estimate "Operating Costs" has been obtained in the Criminal Court because this institution performs the registration of annual expenditures on goods and services needed to ensure proper functioning of both institutions. In the year 2007 it was spent, by the Prosecution Office and by the Criminal Court, 42,015.93 Euros. In the following year, this figure amounted to 48,999.19 Euros. In 2009, 72,292.15 Euros were spent in purchasing goods and services. Ultimately, in 2010 were spent 62,563.55 Euros (Figure 2).

Figure 2: "Operating costs" of Prosecution Office and Criminal Court (2007-2010)

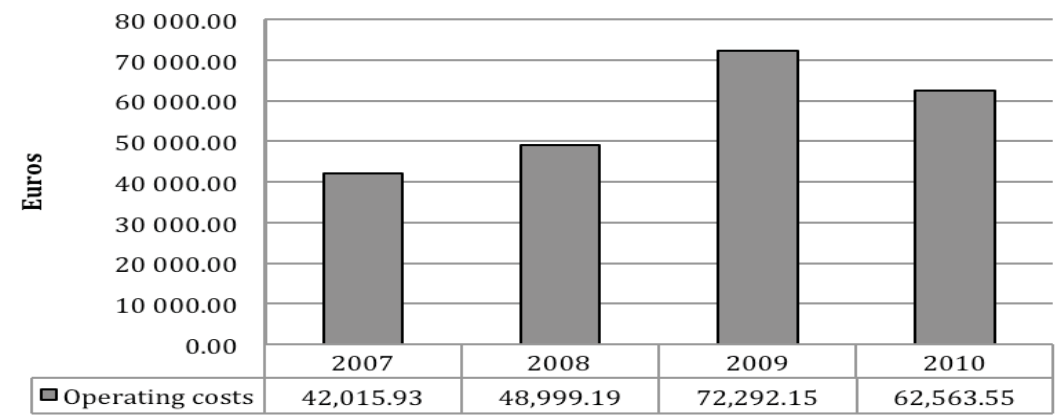

Source: Records of Criminal Court (adapted). Current prices in Euro

The building used by the Prosecution Office and by the Criminal Court belongs to the Government, more specifically to the Office of Financial Management and Infrastructure of the Justice, I.P. Therefore, there is no payment for its use. However, 
the fact that Prosecution Office and Court are operating in this building generates an opportunity cost since, in the absence of this occupation, the building could be rented, generating an income for the Government.

Table 1: Monetary valuation of the building of Prosecution Office and Criminal Court (2007-2010)

\begin{tabular}{|c|c|c|c|c|c|}
\hline & $\begin{array}{l}\mathrm{M}^{2} \\
\text { by } \\
\text { floor }\end{array}$ & $\begin{array}{l}\text { No. of } \\
\text { floors }\end{array}$ & Total $\mathrm{m}^{2}$ & $\begin{array}{c}\text { Monthly rent per } \\
\mathrm{m}^{2} \text { (offices) - } \\
\text { annual average } \\
\text { (Euros) }\end{array}$ & $\begin{array}{c}\text { Monetary } \\
\text { valuation of } \\
\text { building use } \\
\text { (Euros) }\end{array}$ \\
\hline 2007 & \multirow{4}{*}{312} & \multirow{4}{*}{8} & \multirow{4}{*}{$\begin{array}{c}2,496 \\
{[1872]^{*}}\end{array}$} & 8.9027 & $199,990.25$ \\
\hline 2008 & & & & 9.1366 & $205,244.58$ \\
\hline 2009 & & & & 9.0544 & $203,398.04$ \\
\hline 2010 & & & & 9.2564 & $207,935.77$ \\
\hline
\end{tabular}

Source: Elaborated by the authors from data from Customs and Tax Authority; 1st Land Registry of Oporto; Confidencial Imobiliário. Values for the parish of Santo Ildefonso Values in current prices, in Euro

* Useful considered area for renting: $75 \%$.

To the extent that the Criminal Court had no information about the building deployment area, it has been necessary to check data available from the Land Registration Certificate of the building: eight floors with $312 \mathrm{~m}^{2}$ each, gives a total of $2,496 \mathrm{~m}^{2}\left[1,872 \mathrm{~m}^{2}\right.$ of useful area (75\%)]. Using data from a real estate company Confidencial Imobiliário - it was possible to obtain the average annual income per square meter of rented offices, in the parish of Santo Ildefonso. With this information it was possible to compute the monetary valuation of the building use, for the analysed years, and to achieve the value for the costs of building use (cf. Table 1).

Finally, summing up all the costs, we get the information presented in Table 2 that shows the total expenses of the Prosecution Office and of the Criminal Court. In order to compute the costs of drivers' crimes, by proportional allocation, it was necessary to know the total incoming processes in each of the years, respective crimes and the followed proceedings in the Prosecution Office and in the Criminal Court ${ }^{7}$.

\footnotetext{
${ }^{7}$ It was assumed that the costs might be different according to the followed proceedings.
} 
Table 2: Total expenses of Prosecution Office and Criminal Court (2007-2010)

\begin{tabular}{|c|c|c|c|c|}
\hline Years & 2007 & 2008 & 2009 & 2010 \\
\hline & Total annual & Total annual & Total annual & Total annual \\
\hline "Staff-related costs" & $1,076,629.56$ & $1,060,075.41$ & $1,188,469.10$ & $1,138,684.28$ \\
\hline "Operating costs" & $42,015.93$ & $48,999.19$ & $72,292.15$ & $62,563.55$ \\
\hline "Building costs" & $199,990.25$ & $205,244.58$ & $203,398.04$ & $207,935.77$ \\
\hline Total & $1,318,635.74$ & $1,314,319.18$ & $1,464,159.29$ & $1,409,183.60$ \\
\hline
\end{tabular}

Source: Elaborated by the authors. Values in current prices, in Euro

Table 3: Number and Type of Cases Brought into Criminal Court (2007-2010)

\begin{tabular}{|l|r|r|r|r|}
\hline \multicolumn{1}{|c|}{ Years } & \multicolumn{1}{c|}{2007} & \multicolumn{1}{c|}{2008} & \multicolumn{1}{c|}{2009} & \multicolumn{1}{c|}{2010} \\
\hline & No. of cases & No. of cases & No. of cases & No. of cases \\
\hline Crimes judged & 2,302 & 2,464 & 2,395 & 2,376 \\
\hline Crimes suspended $^{8}$ & 0 & 357 & 1,084 & 910 \\
\hline Contraventions & 334 & 349 & 335 & 262 \\
\hline Transgressions & 8 & 0 & 0 & 0 \\
\hline Other processes & 56 & 46 & 29 & 28 \\
\hline Total & 2,700 & 3,216 & 3,843 & 3,576 \\
\hline
\end{tabular}

Source: Elaborated by the authors from statistics and records of Prosecution Office and

Court.

In the Court, we found that processes were classified only according to their type, namely, contraventions, transgressions, criminal proceedings and other proceedings. Criminal proceedings were categorised as "common process" (collective and singular) and "special process" (sumário, sumaríssimo and abreviado) (vide Table 3).

Because statistics produced by the Criminal Court have not provided evidence about the type of offence referred to in process - essential to the accomplishment of our pre-established objectives -, it was necessary to draw a strategy to obtain this information. Therefore, we opted for the consultation of a sample of faxes received by the Prosecution Office during the period under review. Whenever someone was arrested under the suspicion of having committed a criminal act, a fax was sent to

\footnotetext{
${ }^{8}$ In addition to not provide information about the type of crime, the judicial statistics also did not have information on the number of processes that have been suspended. Therefore, it was necessary to consult the records of the Prosecution Office with the purpose of determining the number of suspended processes, according to the type of crime. Information about these data is presented later in this text.
} 
the Prosecution Office located in the court with jurisdiction to proceed with the trial. In that fax, among other information, it was described the type of crime and the date when it took place.

The sample of faxes concerning crimes detected and prosecuted in the Criminal Court was comprised of 5,989 cases. Of this total, 2,733 faxes (46\%) concerned the crime of drunk-driving, 1,991 (33\%) were related to the crime of driving without legal license, and 1,265 (21\%) were related to other crimes. After, we computed the share of each judged crime in the total of sampled processes, for each year (Table 4).

Table 4: Sample of Criminal Proceedings (Judged) and Respective Type of Crime (2007-2010)

\begin{tabular}{|l|c|c|c|c|c|}
\hline $\begin{array}{l}\text { Values and proportions } \\
\text { in the sampled processes }\end{array}$ & 2007 & 2008 & 2009 & 2010 & Total \\
\hline Total of judged crimes & 1,795 & 1,982 & 1,148 & 1,064 & 5,989 \\
\hline $\begin{array}{l}\text { Crime of drunk-driving } \\
\text { (DD) }\end{array}$ & $\begin{array}{c}892 \\
{[0.496936]}\end{array}$ & $\begin{array}{c}970 \\
{[0.489405]}\end{array}$ & $\begin{array}{c}394 \\
{[0.343206]}\end{array}$ & $\begin{array}{c}477 \\
{[0.448308]}\end{array}$ & 2,733 \\
\hline $\begin{array}{l}\text { Crime of driving without } \\
\text { legal license (DWL) }\end{array}$ & $\begin{array}{c}702 \\
{[0.391086]}\end{array}$ & $\begin{array}{c}645 \\
{[0.325429]}\end{array}$ & $\begin{array}{c}381 \\
{[0.331882]}\end{array}$ & $\begin{array}{c}263 \\
{[0.247180]}\end{array}$ & 1,991 \\
\hline Others crimes (OC) & $\begin{array}{c}201 \\
{[0.111978]}\end{array}$ & $\begin{array}{c}367 \\
{[0.185166]}\end{array}$ & $\begin{array}{c}373 \\
{[0.324913]}\end{array}$ & $\begin{array}{c}324 \\
{[0.304511]}\end{array}$ & 1,265 \\
\hline
\end{tabular}

Source: Elaborated by the authors from Prosecution Office records.

With the proportions shown in Table 4 it has been possible to determine the number of processes for each specific type of crime, entered in the Prosecution Office and in the Criminal Court. Using a process of point estimation, the reasoning has been as follows: in 2007 the sample proportion of the crimes of drunk-driving that were judged was about 0.4969 . Then, a best guess for that type of crime in 2007 will be 1,144 (i.e., $0.4969 \times 2,302$ ). The same reasoning applies to the other cases - see Table 5.

Table 5: Number of Cases Brought in the Prosecution Office and Criminal Court, According to the Type of Crime (2007-2010) (Judged)

\begin{tabular}{|l|c|c|c|c|}
\hline & 2007 & 2008 & 2009 & 2010 \\
\hline Judged Crimes & 2,302 & 2,464 & 2,395 & 2,376 \\
\hline DD & 1,144 & 1,206 & 822 & 1,065 \\
\hline DWL & 900 & 802 & 795 & 587 \\
\hline OC & 258 & 456 & 778 & 724 \\
\hline
\end{tabular}

Source: Elaborated by the authors from Prosecution Office and Court Records. 
Table 6: Number of Cases Brought in the Prosecution Office and Court, in Accordance to the Type of Crime (2007-2010) (Suspended)

\begin{tabular}{|l|c|c|c|c|c|}
\hline & 2007 & 2008 & 2009 & 2010 & Total \\
\hline Suspended crimes & 0 & 357 & 1,084 & 910 & 2,351 \\
\hline DD & 0 & 267 & 875 & 749 & 1,891 \\
\hline DWL & 0 & 75 & 194 & 155 & 424 \\
\hline OC & 0 & 15 & 15 & 6 & 36 \\
\hline
\end{tabular}

Source: Elaborated by the authors from Prosecution Office records.

In order to compute the number of processes that were temporarily suspended, we accessed Prosecution Office records to find, initially, the total number of cases $(N=2,351)$. Secondly, we analysed the type of crime (Table 6). Of the total cases, 1,891 were related to the crime of drunk-driving (80\%), 424 were related to the crime of driving without license (18\%) and 36 were related to other crimes (2\%).

\section{COSTS OF DRIVERS' CRIMES - FINAL RESULTS}

In previous sections, we presented data about the number and the type of crimes recorded in the Prosecution Office and in the Criminal Court during the time period under study. To find estimates of the costs of drivers' crimes, it has been needed to know the proportion of these acts in the total of cases registered in the Prosecution Office (PO) and Court (Table 7 and 8), in order to, afterwards, allocate the respective costs (Table 9).

Table 7: Number and Proportion of Drivers' Crimes (Judged) in the Total of Processes Entered in the Prosecution Office and Criminal Court (2007-2010)

\begin{tabular}{|c|c|c|c|c|c|}
\hline & $\begin{array}{c}\text { Total Entered } \\
\text { Processes in the } \\
\text { PO and Court (a) }\end{array}$ & $\begin{array}{c}\text { No. of } \\
\text { crimes of } \\
\text { DD (b) }\end{array}$ & $\begin{array}{c}\text { Proportion of } \\
\text { crimes of DD } \\
\text { (b/a) }\end{array}$ & $\begin{array}{c}\text { No. of } \\
\text { crimes of } \\
\text { DWL (c) }\end{array}$ & $\begin{array}{c}\text { Proportion of } \\
\text { crimes of DWL } \\
\text { (c/a) }\end{array}$ \\
\hline 2007 & 2,700 & 1,144 & 0.423704 & 900 & 0.333333 \\
\hline 2008 & 3,216 & 1,206 & 0.375000 & 802 & 0.249378 \\
\hline 2009 & 3,843 & 822 & 0.213895 & 795 & 0.206870 \\
\hline 2010 & 3,576 & 1,065 & 0.297819 & 587 & 0.164150 \\
\hline
\end{tabular}

Source: Elaborated by the authors from Prosecution Office and Court Data. 
Table 8: Number and Proportion of Drivers' Crimes (Suspended) in the Total of Processes Entered in the Prosecution Office and Criminal Court (2007-2010)

\begin{tabular}{|c|c|c|c|c|c|}
\hline & $\begin{array}{c}\text { Total Entered } \\
\text { Processes in the } \\
\text { PO and Court (a) }\end{array}$ & $\begin{array}{c}\text { No. of } \\
\text { crimes of } \\
\text { DD (b) }\end{array}$ & $\begin{array}{c}\text { Proportion of } \\
\text { crimes of DD } \\
\text { (b/a) }\end{array}$ & $\begin{array}{c}\text { No. of } \\
\text { crimes of } \\
\text { DWL (c) }\end{array}$ & $\begin{array}{c}\text { Proportion of } \\
\text { crimes of DWL } \\
\text { (c/a) }\end{array}$ \\
\hline 2007 & 2,700 & 0 & 0 & 0 & 0 \\
\hline 2008 & 3,216 & 267 & 0.083022 & 75 & 0.023321 \\
\hline 2009 & 3,843 & 875 & 0.227687 & 194 & 0.050481 \\
\hline 2010 & 3,576 & 749 & 0.209452 & 155 & 0.043345 \\
\hline
\end{tabular}

Source: Elaborated by the authors from Prosecution Office and Court Data.

Table 9: Total Costs of the Prosecution Office and Criminal Court Allocated to Drivers' Crimes (2007-2010)

\begin{tabular}{|c|c|c|c|c|c|c|}
\hline \multirow{2}{*}{ Year } & \multirow{2}{*}{$\begin{array}{l}\text { Total costs of } \\
\text { PO and Court }\end{array}$} & \multirow{2}{*}{$\begin{array}{l}\mathrm{DD}+\mathrm{DWL} \\
\text { crimes }\end{array}$} & \multicolumn{2}{|c|}{ Costs of DD crime } & \multicolumn{2}{|c|}{ Costs of DWL crime } \\
\hline & & & Totals & $\begin{array}{l}\text { Suspended (S) } \\
\text { \& Judged (J) }\end{array}$ & Totals & $\begin{array}{l}\text { Suspended } \\
\text { (S) \& } \\
\text { Judged (J) }\end{array}$ \\
\hline 2007 & $1,318,635.74$ & $\begin{array}{r}998,256.10 \\
{[75,70 \%]} \\
\end{array}$ & $558,710.85$ & $\begin{array}{lr}\text { S: } & 0 \\
\mathrm{~J}: & 558,710.85 \\
\end{array}$ & $439,545.25$ & $\begin{array}{lr}\text { S: } & 0 \\
\mathrm{~J}: & 439,545.25 \\
\end{array}$ \\
\hline 2008 & $1,314,319.18$ & $\begin{array}{r}960,401.14 \\
{[73,07 \%]} \\
\end{array}$ & $601,987.61$ & $\begin{array}{ll}\text { S: } & 109,117.92 \\
\text { J: } & 492,869.69\end{array}$ & $358,413.53$ & $\begin{array}{lr}\text { S: } & 30,651.10 \\
\mathrm{~J}: & 327,762.43\end{array}$ \\
\hline 2009 & $1,464,159.29$ & $\begin{array}{r}1,023,349.43 \\
{[69,89 \%]} \\
\end{array}$ & $646,546.53$ & $\begin{array}{ll}\text { S: } & 333,369.60 \\
\mathrm{~J}: & 313,176.93 \\
\end{array}$ & $376,802.90$ & $\begin{array}{lr}\text { S: } & 73,912.80 \\
\mathrm{~J}: & 302,890.10 \\
\end{array}$ \\
\hline 2010 & $1,409,183.60$ & $\begin{array}{r}1,007,235.26 \\
{[71,48 \%]} \\
\end{array}$ & $714,837.54$ & $\begin{array}{ll}\text { S: } & 295,156.18 \\
\text { J: } & 419,681.36 \\
\end{array}$ & $292,397.72$ & $\begin{array}{lr}\text { S: } & 61,080.39 \\
\text { J: } & 231,317.33 \\
\end{array}$ \\
\hline Total & $5,506,297.81$ & $\begin{array}{r}3,989,241.93 \\
{[72,45 \%]} \\
\end{array}$ & $2,522,082.53$ & $\begin{array}{lr}\text { S: } & 737,643.70 \\
\text { J: } & 1,784,438.83\end{array}$ & $1,467,159.40$ & $\begin{array}{l}\text { S: } 165,644.29 \\
\text { J: } 1,301,515.11\end{array}$ \\
\hline
\end{tabular}

Source: Elaborated by the authors from Prosecution Office and Court Data. Values in current prices, in Euro

During the analysed period, total estimated costs of Prosecution Office and Criminal Court varied between 1,314,319.18 Euros and 1,464,159.29 Euros. Of this amount, approximately three quarters were spent with the prosecution and judgement of the drivers' crimes. The crimes of drunk-driving that were suspended ${ }^{9}$ originated an average cost, in the analysed period, of $184,410.93$ Euros. When these crimes were judged, the average cost was 446,109.71 Euros. In total, this type of crime cost, on average, 630,520.63 Euros.

\footnotetext{
${ }^{9}$ In 2007 there were no suspensions in both analyzed crimes because this legal institute has been applied only from 2008.
} 
In turn, the crimes of driving without legal license imposed an average cost, when suspended, of $41,411.07$ Euros. When these crimes were judged, the average cost was $325,378.78$ Euros. In total, this type of crime cost, on average, 366,789.85 Euros.

During the period 2007-2010, drivers' crimes imposed a total cost of 3,989,241.93 Euros, with an annual average of $997,310.48$ Euros. In order to have a better picture regarding social burden, it is possible to translate monetary values into the per capita contribution to the Gross Domestic Product of the Oporto Metropolitan administrative area (named Grande Porto).

It is possible to say that the average estimated costs of the crime of drunk-driving, in the period under analysis, has been equal to the average contribution of 38 citizens to the GDP regional value during 2007-2010. In turn, we can conclude that the average estimated costs of the crime of driving without license, in the period under analysis, has been equal to the average contribution of 22 citizens to the GDP regional value in the same period. In general, the drivers' crimes imposed an average cost in the analysed period that corresponded to the average contribution of 61 citizens to the GDP regional value.

This empirical evidence is important, as these estimated values will be reflected in higher taxes paid by ordinary taxpayers, or in losses in public services whose supply could be reduced. Finally, it is important to emphasize that these values could be underestimated as a result of a limitation in our calculus. This limitation relates to the fact that the "staff-related costs" were indirectly computed and, therefore, could not reflect the (higher) true amount spent by the Government with Prosecution Office and Court employees.

\section{CONCLUSIONS}

In recent decades, in Criminology, researchers have being increasingly focused on the criminal justice system as an object of study, as William (1984) had anticipated several years ago. One of the consequences of this focus is the increasing number of studies attempting to estimate the costs of crime in various countries of Europe and America. In contrast, in Portugal this area of research is embryonic.

It was the identification of this fact as a shortcoming for the Portuguese public policy decision-making, coupled with the recognition of the importance of this area of research, that led us to a project that had as an objective the computation of the costs of crime, specifically, the costs of law enforcement. The analysis was narrowed to two very specific criminal acts, drivers' crimes - driving under the influence of alcohol, drugs or psychotropic substances (Penal Code, article 292) and driving 
without legal license (Decree-Law No. 2/98, article 3). These are behaviours with a high incidence in Portugal, possibly generating high costs that, ultimately, fall on all taxpayers.

In this chapter we presented empirical evidence according to which the total cost of law enforcement in both drivers' crimes reached the annual average of 997,310.48 Euros, between 2007 and 2010. It is an important value when we think that it will imply higher taxes or lower supply of other public services. In particular, that value meant, in each year, a well-fare sacrifice equivalent to the value added by 61 productive citizens of the Oporto metropolitan administrative zone (named Grande Porto) to the Gross Domestic Product.

In addition to having presented scientific data about the costs of drivers' crimes, this study also aimed to survey the type of data contained in several institutions that are part of the justice system, and to test a methodology to calculate their aggregated costs. The strategy used was "the possible" one, due to constraints in time to make the research and in the availability of reliable data.

In future research, it would be desirable that the allocation of the expenditures be done based not in the incidence of each type of crime, but in the duration of the processes in each type of crime, and at each step of the proceedings. This will make the allocation of expenses more valid since some crimes may involve more steps than others, which possibly translates into higher costs.

In what respects to drivers' crimes, there are other entities (e.g., police, prisons, inter alia) that are important in the process and that generate costs, but are not considered in this chapter. They will be analysed in other papers of ours. Finally, it would be of utmost importance that the task of calculating the costs of crime can be extended to the entire national territory, to the various types of crime and to different types of costs. This is the only way to have a better picture of the impact of criminal phenomenon in a country. Decisions on public programs and prevention measures to be implemented in the future should be based on comparisons between the costs of its implementation and the benefits, evaluated in terms of reducing the incidence of crime. In those analyses, the costs of crime occupy an important place.

\section{References}

[1] Albertson, K., \& Fox, C. (2008). Estimating the costs of crime in England and Wales. Safer Communities, 7(4), 25-33.

[2] Anderson, D. A. (1999). The Aggregate Burden of Crime. Journal of Law and Economics, 42(2), 1-57. 
[3] Atkinson, G., Healey, A., \& Mourato, S. (2005).Valuing the costs of violent crime: a stated preference approach. Oxford Economic Papers, 57, 559-585.

[4] Brand, S., \& Price, R. (2000). The economic and social costs of crime. Home Office Research Study 217.

[5] Christe, N. G. S., \& Soguel, N. C. (1996). The pain of road-accident victims and the bereavement of their relatives: a contingent-valuation experiment. Journal of Risk and Uncertainty, 13, 277-291.

[6] Cohen, M. A. (1988). Pain, suffering, and jury awards: A study of the cost of crime to victims. Law \& Society Review, 22, 537-556.

[7] Cohen, M. A. (1990). A Note on the Cost of Crime to Victims. Urban Studies, 27(1), 139-147.

[8] Cohen, M. A. (1998). The monetary value of saving a high-risk youth. Journal of Quantitative Criminology, 14(1), 5-33.

[9] Cohen, M. A. (2000). Measuring the Costs and Benefits of Crime and Justice. In: National Institute of Justice (Ed.), Measurement and analysis of crime and justice, 4, 263-315.

[10] Cohen, M. A., \& Miller, T. R. (2003). "Willingness to award" nonmonetary damages and the implied value of life from jury awards. International Review of Law and Economics, 23, 165-181.

[11] Cohen, M. A., Rust, R. T., Steen, S., \& Tidd, S. T. (2004). Willingness-to-pay for crime control programs. Criminology, 42(1), 89-110.

[12] Czabanski, J. (2010). Estimates of cost of crime: history, methodologies, and implications. Springer: Poland.

[13] Detotto, C., \& Vannini, M. (2010). Counting the cost of crime in Italy. Global Crime, 11, 421-435.

[14] Direção-Geral da Administração e do Emprego Público (2007). Sistema Retributivo da Administração Pública. Available at www.dgap.gov.pt/

[15] Direção-Geral da Administração e do Emprego Público (2008). Sistema Retributivo da Administração Pública. Available at www.dgap.gov.pt/

[16] Direção-Geral da Administração e do Emprego Público (2009). Sistema Retributivo da Administração Pública. Available at www.dgap.gov.pt/

[17] Direção-Geral da Administração e do Emprego Público (2010). Sistema Retributivo da Administração Pública. Available at www.dgap.gov.pt/

[18] Dolan, P., Loomes, G., Peasgood, T., \& Tsuchiya, A. (2005). Estimating the intangible victim costs of violent crime. The British Journal of Criminology, 45, 958-976.

[19] Dolan, P., \& Moore, S. C. (2007). From preferences to experiences: valuing the intangible victim costs of crime. International Review of Victimology, 14, 265280.

[20] Dolan, P., \& Peasgood, T. (2007). Estimating the economic and social costs of the fear of crime. The British Journal of Criminology, 47, 121-132. 
[21] Garoupa, Nuno (1997), The theory of optimal law enforcement, Journal of Economic Surveys, vol. 11, No. 3, pp. 267-295.

[22] Godefroy, T., \& Laffargue, B. (1980). Le coût du crime en France en 1976-1977. Service d'Études Penales et Criminologiques. Ministere de la Justice - Direction des Affaires Criminelles et des Graces.

[23] Godefroy, T., \& Laffargue, B. (1989). Les Couts du Crime en France. Données 1984, 1985, 1986 et 1987. Centre des Recherches Sociologiques sur le Droit et les Institutions Pénales, No. 59.

[24] Godefroy, T., \& Laffargue, B. (1995). Les Couts du Crime en France. Estimation Monetaire des Criminalites. Données pour 1988 a 1991. Centre des Recherches Sociologiques sur le Droit et les Institutions Pénales, No. 71.

[25] Graça, J. M., \& Ramos, M. J. (2000). A Insegurança rodoviária e a gestão da Impunidade. Em: E. M. d. Neves, F. G. Pinto \& L. T. Quaresma (coords.), Actas do I Congresso Rodoviário Português ESTRADA 2000 - A Qualidade Rodoviária na Viragem do Século. Organizado pelo Centro Rodoviário Português. Lisboa LNEC, November, 28-30 2000. Vol. 3, Lisbon, Congresso Rodoviário Português.

[26] Instituto de Segurança Social (2011). Guia Prático - Regime de Proteção Social de Trabalhadores em Funções Públicas.

[27] Mayhew, P. (2003). Counting the Costs of Crime in Australia. Trends and Issues in Crime and Criminal Justice, 247. Australian Institute of Criminology, Canberra.

[28] Miller, T. R., Cohen, M. A., \& Rossman, S. B. (1993). Victim costs of violent crime and resulting injuries. Health Affairs, 12(4), 186-197.

[29] Miller, T. R., Cohen, M. A., \& Wiersema, B. (1996). Victim Costs and Consequences: A New Look. National Institute of Justice, Research Report.

[30] Palle, C., \& Godefroy, T. (1998), Coûts du Crime. Une Estimation Monétaire des Délinquances. 1992-1996. Centre des Recherces Sociologiques sur le Droit et les Institutions Pénales, No. 79.

[31] Polinsky, A. Mitchell and Steven Shavell (2000). Public enforcement of law, in: Bouckaert, Boudewijn and De Geest, Gerrit (eds.), Encyclopedia of Law and Economics, Volume I. The History and Methodology of Law and Economics, Cheltenham, Edward Elgar.

[32] Rollings, K. (2008). Counting the costs of crime in Australia: a 2005 update. Research and Public Policy Series, 91. Australian Government. Australian Institute of Criminology.

[33] Roper, T., \& Thompson, A. (2006). Estimating the costs of crime in New Zealand in 2003/05. New Zealand Treasury, 06/04.

[34] Soeiro, M., \& Teixeira, A. A. C. (2010). Determinants of higher education students' willingness to pay for violent crime reduction: a contingent valuation study. FEP Working Papers, No. 384.

[35] William III, F. P. (1984). The demise of the criminological imagination: a critique of recent criminology. Justice Quarterly, 1, 91-106. 


\section{Laws}

[1] Código Penal. (2011). Almedina.

[2] Código de Processo Penal. (2011). Almedina.

[3] Decreto-Lei n.o 26/2002, (14 Feb 2002). Diário da República No. 38 - I Série-A. Ministério das Finanças. 